\title{
On the Cultivation of Non-intellective Factors in Chinese Teaching
}

\author{
Liu Zhenying \\ Teaching and Research Department of Cultural Lessons \\ Competitive Sports School, Wuhan Sports University \\ Wuhan, China
}

\author{
Wang Yun \\ Wuhan Sports University \\ Wuhan, China
}

\begin{abstract}
Non-intellective factors play a significant and positive role in sports school students' cultural course learning and their growth and development. Chinese teaching has unique advantages in the cultivation of students' non-intellective factors. Taking Chinese teaching as an entry point, this paper investigated the cultivation of non-intellective factors by developing learning interest, stimulating learning motivation, clarifying learning objectives, mastering learning methods, fulfilling learning tasks and strengthening learning will. Teaching practice indicates that, with the cultivation of non-intellective factors penetrating in classroom teaching, students' learning enthusiasm has been greatly increased, while their confidence to overcome the study difficulties has been enhanced and their learning methods perfected, which results in the improvement of their learning efficiency and academic performance.
\end{abstract} factors

Keywords-sports school; Chinese; teaching; non-intellective

\section{INTRODUCTION}

Non-intellective factors are psychological factors besides intelligence and ability that interact with the benefits of intellectual activities, such as interest, emotion and attitude. Non-intellective factors do not directly involved in learning activities, but work with intellective factors together to influence the entire learning process. Non-intellective factors act as motivation and compensation for the development of intelligence ${ }^{[1]}$. Chinese people have formed the understanding of non-intellective factors since ancient times. In the old saying "I am unable' does not mean that I have no ability, but means that I do not make any effort", "ability" is an intellective factor while "effort", which means "willingness", is a non-intellective factor. The well-known smart child Fang Zhongyong, who can compose a poem immediately after anyone refers to an object, does have high intelligence. But due to lack of the cultivation of non-intellective factors, he grows up only to be a common person. Intelligence is reliable and successful study is obtainable only when people pay attention to the effect of non-intellective factors ${ }^{[2]}$. In modern society, as people are facing more changes and challenges in study and work, it involves more non--intellective factors such as motivation, emotion, attitude, determination and belief to nurture elite athletes and create outstanding sports performance. Chinese is a compulsory and fundamental cultural course for sports school students. With its dual essential of instrumentality and humanity, Chinese not only can help students to cultivate intellective factors, for example, increase their knowledge, broaden their horizons, activate their thinking and develop their abilities, but also can inspire students' learning interest, cultivate their taste, develop their personality and shape their character, as well as has unique advantages and resources in cultivation of non-intellective factors such as emotion, attitude, interest, motivation, will and traits $^{[3]}$. In order to explore ways to cultivate non--intellective factors in Chinese teaching in sports schools, to promote the cultural-course learning and health development of athlete students, the author made the following investigation.

\section{CULTIVATE LEARNING INTEREST AND STIMULATE LEARNING MOTIVATION}

Interest is the psychological tendency of an individual to actively explore certain things or conduct certain activities. Students can positively pay attention to and take part in classroom study only when they have the interest. As it goes in the saying, "Who likes is better than one knows, who enjoys is better than who likes". The educator Tao Xingzhi once said, "When students have interest in something, they would put full efforts in doing it, which indicates that learning and joy cannot be separated." Many young athletes do not study hard and often skip classes. The main reason behind this, except for intensive training and lack of energy for learning, is that they has poor foundation and are not interested in cultural-course learning. Therefore, Chinese teaching should, based on the practical reality, cultivate students' interest in Chinese, stimulate their internal motivation and bring students' nonintellective factors into full play so as to encourage their intelligence development ${ }^{[4]}$.

To cultivate students' interest in learning, first the teacher should explore and make use of the rich connotation of Chinese textbooks. Chinese textbooks are comprehensive: an article in the textbooks can be a personal writing as well as reflection of a certain era. Due to limited learning time after classes, athlete students in sports schools usually lack the knowledge of literature and history. In the teaching of reading class, if teachers can, based on different types of articles, introduce to students some information like the life and values of the author, historical background of the article, students will understand the article more easily and have sympathy with the author's idea and emotion, which thereby reduces reading difficulty and stimulate students' interest in learning. As in 
teaching the lesson of Zhu Zhiwu Causes the Withdrawal of Qin's Army, the teacher could first introduce to students the historical background of Jin State and Qin State besieging Zheng State. Duke Wen of Jin, on one hand, is to take revenge on Zheng State, on the other hand, he wants to expand his state territory and fight for hegemony. Qin State, as an ally of Jin State, also wants to benefit from the war and expand the state territory. Once knowing that alliance stems from the common interests of both states, students can gain a deeper understanding of how Zhu Zhiwu take advantage of the interests of both states to put an end to the war. "Alliance derived from interests is bound to be broke off because of other interests." "If there are greater interests than what Zhu Zhiwu has committed, Duke Mu of Qin must turn his back on Zhu and seek those interests." When students can comprehend the meaning of above sentences, they can surely analyze, from the perspective of interests, that why counties in the world have different attitude towards international affairs such as regional disputes, nuclear crisis and terrorism. Through a comprehensive grasp of the background knowledge of political, economic, cultural and ideological status in the author's age, students can obtain better perception of life, deeper understanding of society, wider application of their knowledge, and gradually produce strong interest in learning.

To cultivate students' interest in learning, the teacher should change the stereotyped teaching patterns to avoid taking everything into consideration and plain and dull teaching method. For teachers, how to choose a teaching method and design the teaching pattern should be based on the stylistic and structural features of the article. Teachers should guide students to learn by following the idea of the article. The thread of an article can be longitudinal or horizontal. An article is an organic whole organized by certain relations such as primary and secondary, cause and effect, static and dynamic and detailed and brief. If students can grasp the thread of the article, follow the idea of the author, their learning process would be like a winding path which leads to a secluded but enchanting view. In this way, students' thinking will always be in a state of growth and exploration; and Chinese learning is no longer the boring indoctrination of characters, words, sentences and paragraphs. Instead, Chinese learning will be full of fun and students' reading abilities and interests are also gradually improved in the process.

By the observation in one-semester teaching practice, it is found that in spite of the mobility of the author's class, most of the students can focus on the lessons in Chinese classes and have keen interest in learning; some even positively ask and answer questions; less students would sleep, chat and play with mobile phones in the class: the class atmosphere is greatly improved.

\section{Clarify LEARNING OBJECTIVE AND MASTER LEARNING METHODS}

Learning objective is the starting point of learning. To clarify the learning objective can bring students a clear direction of learning and stimulate students' learning potential so that they can devote themselves to learning. Under great pressure of training and competitions, athlete students in sports schools have less time to learn and cannot preserve in learning. Based on students' actual situation and study needs, based on the building of knowledge system and cultivation of Chinese attainments, we carefully analyzed the textbooks according to the requirement of teaching syllabus, optimized the structure of textbooks, and finally developed an appropriate, specific and realistic learning objective and method. With the help of clear learning objectives and methods, students' initiative and creativity is stimulated.

The article Moonlight over the Lotus Pond in Unit One, Chinese Book Two of high schools is a lyrical prose. It describes a beautiful view of lotus pond under the moonlight by using rhetoric speeches like metaphor, antithesis and personification. The overall reading objective and learning method of Unit One is set as follows:

TABLE I. THE OVERALL READING OBJECTIVE AND LEARNING METHOD OF UNIT ONE

\begin{tabular}{|c|c|c|c|}
\hline Unit & Articles & Reading Objectives & $\begin{array}{c}\text { Learning Meth- } \\
\text { ods }\end{array}$ \\
\hline $\begin{array}{c}\text { Unit } \\
\text { One: } \\
\text { Prose of } \\
\text { scenery }\end{array}$ & $\begin{array}{c}\text { Moonlight } \\
\text { over the Lotus } \\
\text { Pond } \\
\text { Autumn in } \\
\text { Hometown } \\
\text { Imprison the } \\
\text { Green }\end{array}$ & $\begin{array}{l}\text { Understand the rich } \\
\text { emotion expressed in } \\
\text { the prose, ponder over } \\
\text { and learn the writing } \\
\text { method of embedding } \\
\text { the emotion in the } \\
\text { scenery and express- } \\
\text { ing emotion through } \\
\text { scenery }\end{array}$ & $\begin{array}{l}\text { Use association } \\
\text { and imagination, } \\
\text { try to appreciate } \\
\text { the diction }\end{array}$ \\
\hline
\end{tabular}

According to the requirements ("learn the writing method of expressing emotion through scenery", "Use association and imagination and try to appreciate the diction") in the learning objectives, teaching of this article should emphasize on guiding the students to appreciate and analyze scenery description in the fourth, fifth and sixth paragraphs. Take "lotus pond under the moonlight" in the fourth paragraph as an example, the learning method designed for students is as follows:

TABLE II. LEARNING METHOD OF PARAGRAPH FOUR IN MOONLIGHT OVER THE LOTUS POND

\begin{tabular}{|c|c|c|c|c|}
\hline Objects & $\begin{array}{c}\text { Character- } \\
\text { istic }\end{array}$ & $\begin{array}{c}\text { Association } \\
\text { and Imagina- } \\
\text { tion }\end{array}$ & $\begin{array}{c}\text { Rhetoric } \\
\text { Speech }\end{array}$ & Feelings \\
\hline $\begin{array}{c}\text { Lotus } \\
\text { leaves }\end{array}$ & $\begin{array}{c}\text { A silken fie } \\
\text { ld of leaves, } \\
\text { reaching } \\
\text { rather high } \\
\text { above the } \\
\text { surface }\end{array}$ & $\begin{array}{c}\text { Like the skirts } \\
\text { of dancing } \\
\text { girls in all } \\
\text { their grace }\end{array}$ & $\begin{array}{c}\text { Personifica- } \\
\text { tion }\end{array}$ & $\begin{array}{c}\text { Graceful } \\
\text { and beau- } \\
\text { tiful }\end{array}$ \\
\hline
\end{tabular}

In accordance with this table, students need to find in the fourth paragraph the sentences that describe lotus leaf, lotus, lotus aroma and water, in order to taste the beauty of association and imagination, experience the emotion embedded and learn the writing method. The same way shall also be used in the study of the fifth and sixth paragraphs. In the learning process of this lesson, to get a clear understanding of ideas in the article so as to improve reading and writing, and to appreciate the diction and experience the emotion, are important and effective methods in Chinese learning. By 
applying and mastering learning methods, students can get harmonious development of both intellective and nonintellective factors ${ }^{[5]}$.

In brief, with clear learning objective as a guidance and by mastering effective learning methods, students not only can learn well and develop their ability, but also can better cultivate and improve their learning motivation, attitudes, values, emotion and other non-intellective factors. Teachers can actively provide feedback based on teaching evaluation and make adjustment to help students to reach learning objectives, obtain learning achievements, and produce further motivation and desire to learn. Through repeating practice, the author was glad to see that students, after mastering some learning methods, greatly improved their learning initiatives, became the subject of learning and gradually got better academic performance.

\section{FULFILl LEARNING TASKS AND STRENGTHEN LEARNING WILL}

With learning interest and learning methods, one would also need a strong will and tireless efforts to finally grasp a knowledge or skill. As the saying goes, "People who performed great deeds in ancient times need not only extraordinary talent but also indomitable will." An indomitable will is an important condition to overcome difficulties and complete a variety of practical activities ${ }^{[6]}$. Many excellent adolescent athletes are hard working and able to bear hardships. Then how to guide students to carry forward the same spirit in cultural course learning? On the one hand, learning will can be developed in the process of Chinese teaching. For example, in reading class, the teacher can train students to read and recite ancient poems and prose, and take reading notes. In writing class, the teacher can give intensive targeted training to students, set limited writing time to help them develop the habit of serious writing practice; the teacher shall also ask students to pay attention to repetitive writing correction, so that students could appreciate the joy and difficulty in it and cultivate responsibility and the attitude to seek truth from facts. To develop learning will in Chinese teaching process, the teacher shall focus on the teaching method of meticulous lecture and sufficient exercises so that students can form good study habits in listening, speaking, reading, writing and other aspects of learning and training. By fulfilling all kinds of learning tasks, students' learning will is strengthened and the spirit of perseverance is cultivated. On the other hand, the teacher can also make use of the teaching content, like some famous aphorisms and typical stories about pursuit of ideals, perseverance, courage to fight in textbooks, to stimulate students' to attain lofty ideals, overcome difficulties and strengthen learning will. The spirit of perseverance as Xun Zi praised in his essay, "If you persist carving without stopping, you can carve and inlay metal or stone", "Unless you pile up little steps, you can never journey a thousand li; unless you pile up tiny streams, you can never make a river or a sea"; Qu Yuan's persist faith to seek truth as shown in his poem "The way ahead is long; I see no ending, yet high and low I will search with my will unbending."; Hemingway's tough resolve presented in his book, "A man can be destroyed but not defeated": all the content can be good materials to cultivate students' strong will. Finally, the author found in practice that, to require students to be persistent, teachers themselves should be the first to do it. We insisted on timely evaluation of students' study, a small one every month and an overall one by the end of the semester. At the same time, we will provide evaluation results to the coaches and get strong support and cooperation from the coaches. As the cultivation of non-intellective factors penetrating in classroom teaching, students' perseverance and confidence to overcome the study difficulties has been enhanced. Some students changed their study attitude; some students whose study was delayed by training and competition, kept fulfilling their learning tasks under the help of teachers and classmates; some students who have spare time and learning ability even could take the initiative to learn more so as to promote their own development.

Practice has proved that the cultivation of non-intellective factors is of great significance for athlete students' study and growth, and should be an important part of Chinese teaching in sports schools. As long as teachers play a leading role in teaching, and actively promote the cultivation of nonintellective factors such as students' learning interest, behavior and habits, will and quality, morality and emotion, the learning and training conflicts can be better regulated, which will exert positive and profound influence on athlete students' cultural learning and comprehensive development.

\section{REFERENCES}

[1] Lu Jiamei, Psychology of Emotional Education. Shanghai: Shanghai Education Press, 2000.

[2] Chen Juxian, Chinese Pedagogy. Wuhan: Central China Normal University Press, 1998.

[3] The Ministry of Education, Chinese Course Criterion (Tentative Edition). Beijing: Beijing Normal University Press, 2003.

[4] Li Ying, "The cultivation of non-intellective factors in teaching". Adult Education, 2010 (1).

[5] Lin Xiuqiong, "The coordination of intellective and non-intellective factors in Chinese teaching". Education Review, 2007(5).

[6] Shen Deli, Non-intellective Factors and Cultivation of Talents. Beijing: Education Science Press, 1992. 